\title{
FINANCIAL SECURITY FOR THE AGRARIAN SECTOR OF UKRAINE
}

\author{
Nadiia Davydenko' ${ }^{1}$ Prof. dr hab.; Yuliia Bilyak ${ }^{2}, \mathrm{PhD}$; Yuliia Nehoda ${ }^{3}, \mathrm{PhD}$; \\ Nataliia Shevchenko ${ }^{4}, \mathrm{PhD}$ \\ 1,2,3,4 National University of Life and Environmental Sciences of Ukraine, Kyiv, Ukraine
}

\begin{abstract}
The agricultural sector of the economy is system-forming for Ukraine, guarantees the provision of food security of the state, forms the basis for the development of rural territories, influences environmental security, stimulates the development of other sectors of the economy. The level of financial security of the agrarian sector of the Ukrainian economy is caused by a number of factors, such as seasonal nature of production, limited shelf life of products, price disparity, low profitability, etc. Therefore, the purpose of the article is to analyze the development of the agro-industrial complex of Ukraine and the activities of the leading agroholdings of Ukraine, as well as to develop proposals for strengthening the financial security of the agricultural sector based on the results obtained. The goal of the study is based on a systematic approach and comparative economic analysis. The methodological basis is the general scientific methods and mechanisms for ensuring the financial security of enterprises.

The conducted research has made it possible to establish that in recent years the financial security of the agricultural sector in Ukraine is carried out mainly through a set of programs, each of which is aimed at improving production efficiency. Over the past five years, capital investment and credit in agriculture have increased significantly. The article substantiates the need to manage the financial security of agro-industrial enterprises at the present stage of socio-economic development of Ukraine. The practical significance of the obtained results is determined by the fact that the conclusions and proposals can be used in the formation of the financial security strategy of the agricultural sector and the development of a mechanism for its implementation.
\end{abstract}

Key words: financial providing, financial resources, financial security, agrarian sector.

JEL code: D23, Q13, Q14

\section{Introduction}

The purpose of the article is to reveal the specifics of financial support for the agricultural industry, to conduct a systematic analysis of the positive and negative trends that further affect the efficiency of agricultural production, identify the main problems in this field and substantiate the directions of their solution in modern conditions.

The main tasks of the research are: disclosing of scientific approaches to determine the financial support of agricultural enterprises; analysis of financial performance of leading Ukrainian agricultural corporations; assessment of the dynamics of capital investment as one of the sources of financial security; comprehensive assessment of financial support for the agricultural sector of the economy.

Information sources: scientific articles available in international publications, annual financial reports of agricultural enterprises of Ukraine, official data of the National Academy of Agrarian Sciences of Ukraine and the State Statistics Service of Ukraine.

The methodological basis of the article is general scientific and special methods of research, in particular: economic and statistical - to evaluate the dynamics of financial support of the agricultural sector; analysis and synthesis - to find out the reasons that cause changes in the volume of financial security; tabular and graphical - to represent the results of the study; abstract-logical - in the implementation of theoretical and methodological generalizations.

Today agricultural sector of Ukraine is actually the main holder of the budget, and it provides far more than it receives. However, the development of agricultural production in the conditions of

${ }^{1}$ Nadiia Davydenko e-mail address: davidenk@nubip.edu.ua

${ }^{2}$ Yuliia Bilyak e-mail address: gogoniyav@gmail.com

3Yuliia Nehoda e-mail address: negoda@ukr.net

${ }^{4}$ Nataliia Shevchenko e-mail address: 200582_@ukr.net 
Ukraine's accession to the WTO and the intensification of globalization processes is impossible without improving its financing.

The only path for Ukraine to get rid of the role of the commodity country is to increase the added value in the agrarian sector thanks to the development of production capacities of processing products by national producers. High-tech, waste-free production should become the goal of the development in the domestic agrarian sector. It is estimated that the annual yield in Ukraine is within 50-60 million at an internal demand of 20 million tonnes of grain commodity prices, this is only USD 6 billion or $6 \%$ of GDP. By increasing the added value through deeper processing by a factor of five, it is possible to get already USD 30 billion or $+30 \%$ of GDP. This can also be achieved through a transparent and effective mechanism for allocating public subsidies to the agro-industrial complex. It is estimated that a five-fold increasing in value added in the Agro-industrial complex will result in the creation of 1 million new jobs, the multiplier effect will result in the fact that up to UAH 20 of additional GDP can be received for 1 hryvnia invested in the agro-industrial complex. That is due to investments of $1.5 \%$ to GDP will generate up to $30 \%$ of the gross additional product, but with a transparent mechanism of allocation of allocated resources and a system of control over their target using (Davydenko N., 2012).

\section{Research results and discussion}

The formation of the financial support system for the agricultural sector of Ukraine is still ongoing. However, in the context of limited budget resources, instability of public policy in the field of financial support to entrepreneurship and stimulation of alternative forms of financing for agrarian business, lack of effective mechanisms of financial security, accompanied by high levels of financial risks, significant positive financial results and financial resources have not yet been achieved the sector.

The problems of financial support of the agricultural sector are now at the forefront of scientific interests and are reflected in the works of both foreign and domestic scientists. Thus, in particular I. V. Zyatkovsky under the term "financial security" means a system of sources and forms of financing the development of economic and social spheres of society, which is carried out in three forms: self-financing, crediting, budgetary allocations (Zyatkovsky, I., 2000). P. A. Stetsyuk is convinced that the problem of financial support at the micro level is not in the absence of financial resources at all, but in the access to them of a particular enterprise and the forms and methods of their distribution between the industries and economic entities (Stetsyuk, P., 2005).

According to some authors "... the meaning of the concept of" financial support of the enterprise "in a broader sense generalizes a set of measures and conditions that contribute to the sustainable development of the enterprise by covering the costs of the enterprise with financial resources, depending on the size of production and financial situation ..." (Dikan, L. and Holub, Yu., 2007). Accordingly, in the main emphasis in this definition is put on a set of measures and conditions by which it is possible to financially support the activity of the enterprise. O.E. Gudz regards financial security as an opportunity for an economic entity to provide its own activities with the necessary financial resources (Gudz, O., 2007). O. R. Zhydiak believes that when looking for ways to improve the model of rational organizational and economic mechanism of financial support for the activities of agricultural enterprises, it is necessary to take into account various principles: decentralization, compactness, intensity, reduction of intermediate links, dialectical interaction of self-regulation with state regulation, flexibility, flexibility and flexibility etc. (Zhydiak, O., 2013). 
We believe that each of these definitions makes it possible to identify only a portion of the relationships and characteristics that are inherent in the financial support of a particular industry. Given the above, additional research needs financial support for the agricultural sector of the economy.

The financing could be at the expense of own, attracted and borrowed funds. The state supports agricultural sector with instruments of indirect methods, which allow to save financial resources in carrying out certain activities and allow to leave a part of profits which is taxed in other branches of economy.

Indirect methods include the procurement of food for state needs and agricultural products; debt restructuring, regulation of the production market, the establishment of marginal prices for certain types of agricultural enterprises of products, the protection of the economic interests of commodity producers in foreign economic activities in sphere of agro-industrial complex etc.

Increasing production capacity and positions in the consumer market, ensuring favourable organizational and economic conditions for the functioning of the agricultural sector, directing a conditionally direct form of state support through forms of mediation. It includes government procurement, foreign economic customs and tariff regulation, the creation of wholesale markets, the implementation of state programs, the provision of agricultural sector subjects with a machinetractor park on lease or lease conditions, social support for the village and so forth.

Today, financial security of the agrarian sector in Ukraine is carried out mainly through a set of programs, each of which aims to increase the efficiency of production and profitability of the commodity producer. At the same time, due to the lack of funds of the State budget of Ukraine, this support is $80 \%$ administrated at the expense of favorable tax policy, is an indirect form of subsidies to the industry (Shvab A., 2014 and Davydenko N. M., 2012).

Analyzing the State budget of Ukraine for 2017-2018, it can be argued that under the pressure of external and internal factors adopted by the state budget for 2017, a relatively new mechanism for supporting the Agro-industrial complex was formed. Which significantly limited the effect of indirect financing and regulated the annual volume of state budget funds for support of agricultural commodity producers of at least $1 \%$ of production in the agro-industrial complex for 2017-2021.

Table 1

\section{Expenditure pattern of the Ministry of Agrarian Policy and foodstuffs of Ukraine for 2013 - 2018 UAH billion}

\begin{tabular}{|l|c|c|c|c|c|c|c|c|}
\hline \multirow{2}{*}{ Indicators } & \multicolumn{9}{c|}{ Year } & \multicolumn{3}{c|}{ Deviation by \% } \\
\cline { 2 - 9 } & $\mathbf{2 0 1 3}$ & $\mathbf{2 0 1 4}$ & $\mathbf{2 0 1 5}$ & $\mathbf{2 0 1 6}$ & $\mathbf{2 0 1 7}$ & $\mathbf{2 0 1 8}$ & $\begin{array}{c}\mathbf{2 0 1 8} \text { to } \\
\mathbf{2 0 1 3}\end{array}$ & $\begin{array}{c}\mathbf{2 0 1 8} \text { to } \\
\mathbf{2 0 1 7}\end{array}$ \\
\hline Total cost & 7.194 & 5.501 & 2.188 & 2.171 & 9.572 & 15.096 & 210.0 & 157.7 \\
\hline General Fund & 4.175 & 3.359 & 1.613 & 1.691 & 5.565 & 12.769 & 306.0 & 229.5 \\
\hline $\begin{array}{l}\text { Breakdown of costs in the } \\
\text { state budget, \% }\end{array}$ & 58.0 & 61.1 & 73.7 & 77.9 & 58.1 & 84.6 & 145.9 & 145.6 \\
\hline Specific fund & 3.018 & 2.142 & 0.511 & 0.498 & 4.006 & 2.327 & 77.1 & 58.09 \\
\hline $\begin{array}{l}\text { Proportion of expenses in the } \\
\text { state budget, \% }\end{array}$ & 1.78 & 1.28 & 0.37 & 0.32 & 1.20 & 1.97 & 110.67 & 164.17 \\
\hline machine costs, thousand Uah & 3.613 & 2.637 & 0.526 & 0.596 & 5.820 & 7.763 & 214.86 & 133.38 \\
\hline Common Fund & 1.669 & 1.487 & 0.450 & 0.504 & 2.360 & 6.659 & 398.98 & 282.16 \\
\hline Trust fund & 1.944 & 1.150 & 0.076 & 0.092 & 3.461 & 1.105 & 56.84 & 31.93 \\
\hline Lending & 0.623 & 0.021 & 0.381 & 0.087 & 0.842 & 0.952 & 152.81 & 113.06 \\
\hline
\end{tabular}

Source: author's compiled according to the Law of Ukraine State budget for the corresponding year 
The level of agricultural production in 2015 was taken as a basis and fixed at the level of 5500 million UAH budgetary funds (Varnaliy S. S., Anzin R., 2015). This trend has been partly "inherited" by the 2018 state budget for 2018 for the Ministry of Agrarian Policy and Food, 12456 million UAH was provided for expenditures, $94 \%$ of which were planned to be financed from the General Fund (table 1).

In addition to the main financing, it is planned to allocate 952 million UAH credity funds on a returnable basis (without taking into account funds, during the year will be returned by economic entities), and as a whole direct expenditures in the State budget of 2018 for the Ministry of Agrarian Policy and Food reached 13.997 billion UAH, which is $22 \%$ higher than the level of 2017 (Davydenko N., 2018). In the list of budgetary programs to maintain the development of the agrarian sector in 2018 , other programs that were already in place, as well as a new one «Financial security for the development of farms» - was declared as the basis for the development of rural areas (table 2).

According to the data, in 2018, direct budgetary support for the agricultural sector was 4200 million $U A H$, Of which the following expenses are the most important are: - financial support of livestock - 2400 million UAH (58\%), in particular, for partial reimbursement of the cost: construction and reconstruction of livestock farms and complexes and milking halls; purchased for the subsequent reproduction of bodies, netels, cows of native origin and tribal bodies, netels, cows of dairy, dairy and meat direction of productivity, breeding pigs and herds, breeding sheep; sheep, yrock; the reduction of interest on loans for construction, reconstruction of livestock farms and complexes and milecarns.

Table 2

\section{Expenditures on budgetary programs of Ukrainian} AIC development 2013-2018, billion. UAH

\begin{tabular}{|l|c|c|c|c|c|c|c|}
\hline \multicolumn{1}{|c|}{ Program } & Code & $\mathbf{2 0 1 5}$ & $\mathbf{2 0 1 6}$ & $\mathbf{2 0 1 7}$ & $\mathbf{2 0 1 8}$ & $\begin{array}{c}\mathbf{2 0 1 8} \text { to } \\
\mathbf{2 0 1 3}\end{array}$ & $\begin{array}{c}\mathbf{2 0 1 8} \text { to } \\
\mathbf{2 0 1 7}\end{array}$ \\
\hline $\begin{array}{l}\text { Financial assistance for this } \\
\text { option to reduce the cost of } \\
\text { credit }\end{array}$ & 2801030 & 0.291 & 0.280 & 0.300 & 0.266 & 91.41 & 88.66 \\
\hline $\begin{array}{l}\text { Financial support for the } \\
\text { activities in AIC }\end{array}$ & 2801180 & - & - & 0.060 & 0.005 & - & 8.33 \\
\hline Costs of agricultural fund & 2801250 & 0.040 & 0.088 & 0.167 & 0.181 & 452.50 & 108.38 \\
\hline Horticultural support & 2801350 & - & - & 0.075 & 0.400 & - & 533.3 \\
\hline $\begin{array}{l}\text { Financial security for farm } \\
\text { development }\end{array}$ & 2801230 & - & - & - & 0.210 & - & - \\
\hline livestock promotion & 2801450 & 0.040 & 0.030 & 0.170 & 2.401 & 6002.5 & 1412.35 \\
\hline $\begin{array}{l}\text { Financial support to agricultural } \\
\text { producers }\end{array}$ & 2801580 & - & - & 4.774 & 0.695 & - & 14.56 \\
\hline Agricultural support(sum) & & 0.371 & 0.398 & 5.546 & 4.158 & 1120.75 & 74.97 \\
\hline Other activities(sum) & & 0.155 & 0.198 & 0.274 & 0.325 & 209.68 & 118.61 \\
\hline Scientific research & 2801050 & 0.086 & 0.099 & 0.125 & 0.132 & 153.49 & 105.60 \\
\hline Sum & $\mathbf{2 8 0 1 0 0 0}$ & $\mathbf{0 . 5 2 6}$ & $\mathbf{0 . 5 9 6}$ & $\mathbf{5 . 8 2 0}$ & $\mathbf{4 . 4 8 3}$ & $\mathbf{8 5 2 . 2 8}$ & $\mathbf{7 7 . 0 3}$ \\
\hline
\end{tabular}

Source: author's compiled according to the Law of Ukraine State budget for the corresponding year

For 2018, the mechanism for partial compensation to enterprises in the agricultural sector of interest rates on bank loans has been preserved, but significantly below the levels of previous years - only $23 \%$. The expenses under the budget program "Expenses of Agrarian fund", connected with a set of measures on storage, transportation and export of objects of the state price regulation of the state intervention fund, in the amount of 52,2 million UAH. From a special fund, identical to the 
budget for 2017, and under the budget program "Organization and regulation of the activities of institutions in the system of agro-industrial complex and ensuring the activities of "The Agrarian fund", the state budget expenditures in the amount of 128,4 million UAH are provided, including at the expense of the general fund $-86,4$ million UAH.

For the purchase of seeds for the formation of the state reserve seed fund of financial support will be 5 thousand UAH at the expense of the special fund of the state budget.

Overall, there has been no positive growth in support of individual agricultural sector development programs, given that the percentage value of the total expenditure in 2017 is $0.7 \%$, in 2016 $0.25 \%$, in $2015-0.3 \%$. And according to the legislation of Ukraine, the share of the state support expenses of the agrarian sector should be at least $5 \%$ of the expenditure part of the State budget. The real amount of financing does not reach the declared indicators.

Most often, agricultural enterprises use bank credit as the fastest way to attract financial resources. However, high interest rates on the loan, short term of granting of the credit limit the use of this method by agrarian enterprises in the agrarian sector of the economy of Ukraine. For example, average interest rates on loans to agricultural enterprises ranged from $15.9 \%$ in 2010 to $24-26 \%$ in 2015, 17-22 \% in 2017, and 17-24 \% in 2018 (Official site of the National Academy of Agrarian Sciences of Ukraine, 2018).

Bank loans are the main source of small financial resources, mainly for current expenses, updating of production capacities, financing of working capital. The domestic banking system, due to the introduction of progressive credit mechanisms for agrarian enterprises, plays an important role in the continuity of the reproduction process and the development of entrepreneurial activity in the agrarian sector of Ukraine, precisely due to the scale of obtaining funds in comparison with selffinancing.

The study found that today, only operational activities of agricultural enterprises are counted, but there is a scarcity of resources to meet their production needs. (table 3 ).

Table 3

\section{Dynamics of credit ensuring of agrarian sector in Ukraine economy,} 2014-2018 years

\begin{tabular}{|l|c|c|c|c|c|c|}
\hline \multicolumn{1}{|c|}{ Rate } & \multicolumn{3}{c|}{ Years } & $\begin{array}{c}\text { deviation } \\
\mathbf{2 0 1 8} \text { y. to } \\
\mathbf{2 0 1 7} \text { y. }\end{array}$ \\
\cline { 2 - 7 } & $\mathbf{2 0 1 4}$ & $\mathbf{2 0 1 5}$ & $\mathbf{2 0 1 6}$ & $\mathbf{2 0 1 7}$ & $\mathbf{2 0 1 8}$ & 30 \\
\hline $\begin{array}{l}\text { The number of entities that attracted loans, } \\
\text { units. }\end{array}$ & 2267 & 2689 & 2801 & 3011 & 3041 & 3.2 \\
\hline $\begin{array}{l}\text { Loans were given to the agricultural sector - } \\
\text { total, billion UAH }\end{array}$ & 10.9 & 23.4 & 31.5 & 40.3 & 43.5 & 3.7 \\
\hline Short -term & 7.8 & 22.9 & 29 & 36.5 & 38.7 & 2.2 \\
\hline Mid-term & 2 & 0.1 & 2.3 & 3.5 & 4.1 & 0.6 \\
\hline Long - term & 1.1 & 0.4 & 0.2 & 0.3 & 0.7 & 0.4 \\
\hline $\begin{array}{l}\text { Number of subjects that attracted } \\
\text { preferential credits }\end{array}$ & - & 439 & 347 & 382 & 403 & 21 \\
\hline Received concessional loans, million UAH & - & 300 & 162.8 & 294.9 & 653.8 & 358.9 \\
\hline
\end{tabular}

Source: author's calculations based on Association of Ukrainian Banks: Official Internet page and Official site of the National Academy of Agrarian Sciences of Ukraine.

Although loans to the agro-sector by domestic commercial banks increased from 55 billion to 68 billion by $2014-2018$ UAH or $23.6 \%$, its share in the loan portfolio of banking institutions remained almost unchanged, does not correspond to the existing potential of the agricultural sector of the country. 
Analysis of the NBU data on loans provided by non-financial corporations to non-financial corporations on organizational and legal forms of economic activity and currencies (Table 4), indicates that bank lending to domestic farms is low.

Thus, the balance of credit funds to farms at the beginning of 2019 was 6 billion 976 million UAH, which is equivalent to only $0.8 \%$ of total credit mass and $7.9 \%$ of commercial banks loans granted to domestic enterprises. According to this indicator, farms were significantly inferior to domestic state, private and subsidiary enterprises. At the same time, $94 \%$ of the credit balances of farms were in national currency and $6 \%$ - in foreign currency.

\section{Loans granted by deposit corporations (except the National Bank of Ukraine) to non-financial corporations, according to organizational and legal forms of management and currencies at the end of December 2018} (balance of funds at the end of the period, UAH million)

\begin{tabular}{|c|c|c|c|c|c|c|c|}
\hline \multirow{4}{*}{$\begin{array}{l}\text { Organizational and legal } \\
\text { forms of management }\end{array}$} & \multirow{4}{*}{ Sum } & \multicolumn{6}{|c|}{ Among other things } \\
\hline & & \multirow{3}{*}{$\begin{array}{c}\text { In } \\
\text { national } \\
\text { currency }\end{array}$} & \multicolumn{5}{|c|}{ in foreign currency } \\
\hline & & & \multirow[b]{2}{*}{ Sum } & \multicolumn{4}{|c|}{ including by currency } \\
\hline & & & & $\begin{array}{l}\text { Dollar } \\
\text { USA }\end{array}$ & Euro & $\begin{array}{l}\text { russian } \\
\text { ruble }\end{array}$ & $\begin{array}{c}\text { other } \\
\text { currencies }\end{array}$ \\
\hline Sum & $\begin{array}{l}859 \\
740\end{array}$ & 464023 & $\begin{array}{l}395 \\
717\end{array}$ & $\begin{array}{l}325 \\
552\end{array}$ & $\begin{array}{c}69 \\
606\end{array}$ & 486 & 73 \\
\hline Enterprises & 88800 & 40852 & 47948 & 43721 & 3963 & 264 & 1 \\
\hline $\begin{array}{l}\text { Citizen's associations of } \\
\text { enterprises }\end{array}$ & 62 & 50 & 12 & 12 & - & - & - \\
\hline Consumer cooperation & 8 & 8 & - & - & - & - & - \\
\hline individual enterprises & 3 & 3 & - & - & - & - & - \\
\hline family businesses & 48 & 48 & - & - & - & - & - \\
\hline private enterprise & 30026 & 20589 & 9437 & 6858 & 2313 & 264 & 1 \\
\hline collective undertaking & 63 & 52 & 11 & 5 & 6 & - & - \\
\hline $\begin{array}{l}\text { State enterprises, including } \\
\text { state-owned enterprises }\end{array}$ & 40260 & 5931 & 34329 & 33751 & 578 & - & - \\
\hline state public utility enterprise & 1245 & 896 & 348 & 83 & 265 & - & - \\
\hline joint venture & 604 & 563 & 40 & 40 & - & - & - \\
\hline foreign enterprises & 848 & 447 & 401 & 34 & 367 & - & - \\
\hline leased enterprises & 13 & 13 & - & - & - & - & - \\
\hline farm households & 6976 & 6556 & 420 & 88 & 332 & - & - \\
\hline subsidiaries & 8645 & 5695 & 2950 & 2848 & 102 & - & - \\
\hline
\end{tabular}

Source: author's calculations based on Official site of the National Bank of Ukraine

Therefore, the experience of lending US households deserves attention. In the system of crediting of agrarian business, the leading place is occupied by The Farm credit system and the Agency of farmers' Services. In France, independent cooperative banking groups account for more than half of agricultural sector lending. Poland's experience points to a system of cooperative banks through which about $90 \%$ of credits for the agricultural production, processing and trade in agricultural products pass. The system itself has a three-tier structure and consists of the main bank, credit unions and an extensive network of regional and local banks.

The using of this instrument of cooperation with the agricultural sector also demonstrates the high level of preferential lending. Preferential lending is that the farmer pays a certain amount of interest, and the other interest-rate differentials are returned by the state. In Poland, for example, the bank receives funds from the state and distributes them to its regional offices, and they distribute them to borrowers. 
Overall, credit rates have now fallen and profitability in agriculture has fallen, but for many enterprises, credit remains an unaffordable tool for attracting external funds.

Investment is another source of financing for the agricultural sector. After a certain decline in 2014(connected with the political crisis, military events in Ukraine and investors estimates of the expected risks from these events), the pace of investment of domestic agricultural enterprises began to recover. The volume of investments (table 5 ) shows that the agricultural sector is becoming more attractive for investors.

Table 5

Capital investment by economic activity in Ukraine, million UAH

\begin{tabular}{|l|c|c|c|c|c|c|}
\hline \multicolumn{1}{|c|}{ Indicators } & $\mathbf{2 0 1 4}$ & $\mathbf{2 0 1 5}$ & $\mathbf{2 0 1 6}$ & $\mathbf{2 0 1 7}$ & $\mathbf{2 0 1 8}$ & $\begin{array}{c}\mathbf{2 0 1 8 t o} \\
\mathbf{2 0 1 4} \%\end{array}$ \\
\hline Total & 219420 & 273116 & 359216 & 448462 & 526342 & 138.9 \\
\hline $\begin{array}{l}\text { Including Agriculture, hunting and related } \\
\text { services }\end{array}$ & 18388 & 29310 & 49660 & 63401 & 64730 & 252.0 \\
\hline Rural, forest and fisheryhousehold & 18796 & 30155 & 50484 & 64243 & 65901 & 250.6 \\
\hline Industry & 86242 & 87656 & 117754 & 143300 & 179718 & 108.4 \\
\hline $\begin{array}{l}\text { from it food production food, beverage } \\
\text { and tobacco }\end{array}$ & 13487 & 13548 & 21291 & 18927 & 19872 & 47.3 \\
\hline Other economic activities & 40629 & 71081 & 89992 & 115000 & 134398 & 231.0 \\
\hline Construction & 36057 & 43464 & 44444 & 52176 & 51902 & 43.9 \\
\hline $\begin{array}{l}\text { Wholesale and retail trade;repair of } \\
\text { vehicles and motorcycles }\end{array}$ & 20716 & 20663 & 29957 & 33665 & 47597 & 129.8 \\
\hline $\begin{array}{l}\text { Transport, warehousing, postal and } \\
\text { courier activities }\end{array}$ & 15948 & 18704 & 25107 & 37944 & 44921 & 181.7 \\
\hline Temporary accommodation and catering & 1482 & 1393 & 1478 & 2134 & 1904 & -28.5 \\
\hline
\end{tabular}

Source: author's calculations based on the State Statistics Service of Ukraine

In Ukraine, capital expenditures in 2018 amounted to 526342 million UAH, that is $138.9 \%$ more, than in 2014. Considering investments by individual types of economic activity, we see that the increase in the overall indicator is due to increased investments in agriculture, forestry and fisheries - by $250.6 \%$ and industry - by $108.4 \%$, investments in transport, warehousing, postal and courier activities - by $181.7 \%$.

In case of shortage of funds at domestic agrarian enterprises, in our opinion, it is expedient to attract foreign capital into the agricultural sector. Thus, the dynamics of foreign direct investment in the agrarian sector of Ukraine is presented in Fig. 1.

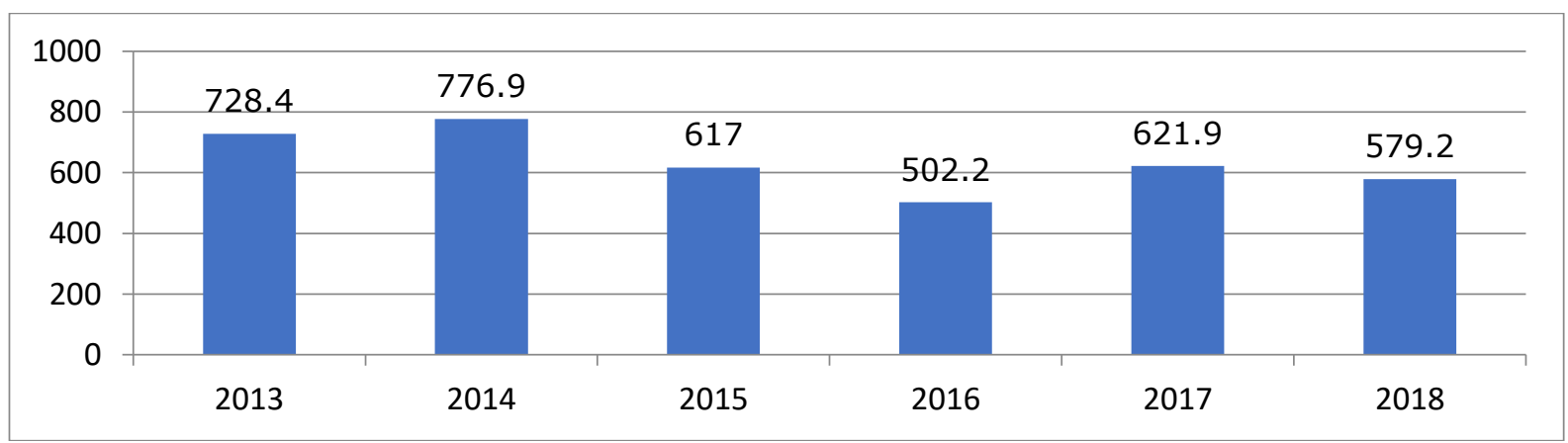

Source: author's calculations based on the State Statistics Service of Ukraine

Fig. 1. Dynamics of foreign direct investment in the share capital of the agrarian sector of Ukraine, million dollars USA

The data show a downward trend of accumulated foreign direct investment in the complex. At the same time, the share of such investments in the total amount of foreign direct investment in Ukraine remains during 2013-2018. A Miniserina $-1.7 \%$ of the total volume. The most direct foreign investment in the agricultural sector is directed to annual and two-year crops, livestock and agricultural support. 
In other words, the state unfortunately failed to create conditions for foreign investment in the agricultural sector to contribute to the qualitative development of the industry. The analysis of the situation with foreign direct investment in agriculture of the country shows that foreign investors today are practically not interested in the long-term development of agricultural enterprises and the industry as a whole, preferring to get more return on the invested funds.

In order to be worthy and successful competitors, it is necessary not only to increase the scope of activity, production capacity, improve the quality of products, but also to manage capital, increase the value of enterprises and the market price of shares, market capitalization.

The increase in market capitalization of the enterprise causes additional interest among investors, which contributes to the inflow of financial resources, increase of the image of the enterprise, increase of the competitiveness of products; the increase in the value of the enterprise increases the improvement of shareholders by increasing the exchange rate value of shares; the increase of capitalization level allows the enterprise to enter the international stock market (Bagatskaya K., 2018).

Table 6 shows information about agro-industrial enterprises in the breakdown of world exchanges.

Table 6

Indicators of Ukrainian agro-industrial enterprises listed on the world stock exchanges as of November 11, 2018

\begin{tabular}{|l|c|c|c|c|c|c|}
\hline $\begin{array}{c}\text { Agro-based } \\
\text { industries. }\end{array}$ & currency & $\begin{array}{c}\text { Capitalization, } \\
\text { mIn dollars }\end{array}$ & $\begin{array}{c}\text { Bid } \\
\text { price }\end{array}$ & $\begin{array}{c}\text { Selling } \\
\text { price }\end{array}$ & $\begin{array}{c}\text { Final } \\
\text { price }\end{array}$ & $\begin{array}{c}\text { Change from } \\
\text { the beginning } \\
\text { of the year }\end{array}$ \\
\hline MHP & USD & 1297 & 12.10 & 12.30 & 12.15 & $5.7 \%$ \\
\hline Kernel Holding & PLN & 1115 & 50.70 & 50.90 & 50.90 & $7.1 \%$ \\
\hline Astarta-Kyiv & PLN & 196 & 29.40 & 29.90 & 29.30 & $-43.1 \%$ \\
\hline Ovostar Union & PLN & 167 & 105.00 & 108.00 & 104.00 & $18.2 \%$ \\
\hline Industrial Milk Company & PLN & 111 & 12.15 & 12.45 & 12.50 & $0.2 \%$ \\
\hline Avangard & USD & 20 & 0.26 & 0.27 & 0.32 & $-11.1 \%$ \\
\hline Agroton & PLN & 20 & 3.42 & 3.49 & 3.40 & $-25.8 \%$ \\
\hline Milkiland & PLN & 7 & 0.61 & 0.75 & 0.80 & $-48.1 \%$ \\
\hline KSG Agro & PLN & 4 & 0.91 & 0.91 & 0.90 & $-55.2 \%$ \\
\hline Ukrproduct & GBP & 2 & 4.50 & 5.00 & 4.75 & $-5.0 \%$ \\
\hline
\end{tabular}

Source: author's calculations based on the State Statistics Service of Ukraine

Thus, two agroholdings of MHP have the largest market capitalization - 1297 million The amount of USD 1,1115 million and Kernel USD 1,215 million Unlike most agro-industrial enterprises, they also have a positive increase in market capitalization since the beginning of the year.

\section{Conclusions}

Conducting the study gives grounds to propose approaches to enhance financial security, in particular the introduction of effective financial management in the field of protection of the priority financial interests of the subjects of agrarian sphere, and in the management of its current activities; development and implementation of methodological support for financial security diagnostics with defined criteria, indicators and levels of its graduation; organization of constant monitoring of financial security; ensuring a high level of capitalization of agrarian business, including through the use of accounting and financial technologies that will help at the level of business entities to enhance financial security and increase investment attractiveness, and at the state level - to provide government statistics with reliable indicators of the activities of agricultural enterprises that will contribute to the effective implementation of agricultural, tax, customs and other policies. 


\section{References}

1. Agriculture of Ukraine. Statistical Collection for 2018 State Statistics Service of Ukraine (2018). Retrieved: http://www.ukrstat.gov.ua Access: 05.02.2020.

2. Association of Ukrainian Banks: Official Internet Page (2018)/ Retrieved: http://www.aub.org.ua. Access: 05.02.2020.

3. Bagatskaya, K. (2018). The Capitalization of Enterprises of Food Industry as a Factor of Increasing of Competitiveness of Products. Retrieved: http://www.khntusg.com.ua/files/sbornik/vestnik_113/31.pdf. Access: 30.01 .2020$.

4. Davydenko, N.M. (2012). Assessment of Efficiency of Attraction of Financial Resources by Agrarian Corporations by Means of Access to Foreign Stock Exchanges and Their Influence on Financial Condition. Vinnitsa Center of Preparation of Scientific and Educational Methodical Editions of the KTEU. 1. p. $308-313$.

5. Davydenko, N.M. (2012). Advantages of Attraction of Financial Resources by Agrarian Corporations by Entering Foreign Stock Exchanges. Volume 3. p. 96 - 101

6. Davydenko, N. (2018). The Financial Support of Agrarian Formations of Ukraine. Kiev 329 p.

7. Dikan, L.V. and Holub, Yu.O. (2007), Financial Support for the Enterprise: The Nature and Sources. Ekonomika Rozytku. Volume 3 (43), pp. 65-68.

8. Gudz, O.Ye. (2007). Provision of Farm Financial Resources in a Time of Change and Stabilization. Ekonomika APK, Volume 3, pp. 46-53.

9. IPO How Successful the Ukrainian Agro-Business in 10 Years Retrieved:https://latifundist.com/infographics/view/60. Access: 30.01.2020.

10. Materials of the Official Site of the National Bank of Ukraine (2019) Retrieved: http://www.bank.gov.ua Access: 27.01.2020.

11. Official Site of the National Academy of Agrarian Sciences of Ukraine (2018). Retrieved: http://naas.gov.ua Access: 27.01 .2020$.

12. Official Site of the National Bank of Ukraine. Loans and Deposits on Organizational and Legal Forms of Management (2018). Retrieved: https://bank.gov.ua/control/uk/publish/article?art_id Access: 27.01.2020.

13. Shvab, A. (2014). The Agro Holdings With Assets in Ukraine on the World Stock Markets. Finance and Taxation. Volume 3 (65). p. $117-124$.

14. Stetsyuk, P.A. (2005) Formation of Financial Resources of Agricultural Enterprises. Ekonomika APK. Volume 11 , pp. $111-116$.

15.Top-200 Agro-Enterprises: How Has the Land Bank of Agroholdings Changed in an Hour (2018). Retrieved: https://delo.ua/business/top-200-ag. Access: 27.01.2020.

16. Varnaliy, S. S., Anzin, R. (2015). The Current State and Dynamics of Public Placements of Domestic Companies' Shares in International Capital Markets. Economic Analysis. Volume 20. p. 114-122.

17. Zhydiak, O.R. (2013). The Problems of the Financial Mechanism of Agrarian Sphere Businesses. Biznesinform, Volume 2, pp. 139-141

18. Zyatkovsky, I.V. (2000), Financial Support of Enterprises. Ekonomichna Dumka. Ternopil. 215 p. 